\title{
Article
}

\section{Sex Work, Sensory Urbanism and Visual Criminology: Exploring the Role of the Senses in Shaping Residential Perceptions of Brothels in Blackpool}

Cooper, Emily, Cook, Ian R. and Bilby, Charlotte

Available at https://clok.uclan.ac.uk/21794/

Cooper, Emily orcid iconORCID: 0000-0003-1013-2755, Cook, Ian R. and Bilby, Charlotte (2018) Sex Work, Sensory Urbanism and Visual Criminology: Exploring the Role of the Senses in Shaping Residential Perceptions of Brothels in Blackpool. International Journal of Urban and Regional Research, 42 (3). pp. 373-389. ISSN 0309-1317

It is advisable to refer to the publisher's version if you intend to cite from the work. http://dx.doi.org/10.1111/1468-2427.12581

For more information about UCLan's research in this area go to http://www.uclan.ac.uk/researchgroups/ and search for <name of research Group>.

For information about Research generally at UCLan please go to http://www.uclan.ac.uk/research/

All outputs in CLoK are protected by Intellectual Property Rights law, including Copyright law. Copyright, IPR and Moral Rights for the works on this site are retained by the individual authors and/or other copyright owners. Terms and conditions for use of this material are defined in the policies page. 


\title{
Sex work, sensory urbanism and aesthetic criminology: Exploring the role of the senses in shaping residential perceptions of brothels in Blackpool
}

\begin{abstract}
Urban studies and criminology have much to offer each other, but there has been little dialogue between the two fields. This paper is an illustration of how aspects of both can, and should, be brought into conversation: namely the literatures on sensory urbanism (in urban studies) and aesthetic criminology. The benefits of doing so are evidenced by a case study exploring the ways in which the senses shape residents' perceptions of brothels in Blackpool. Three key findings emerge from the case study. Firstly, the residents interviewed tended to focus on the visual aspects of brothels rather than other sensory aspects. Nevertheless, touch and smell (and their interaction with the visual) also played small but important roles in shaping residential perceptions. Secondly, residential perceptions of sex work and brothels are linked to, and encompass, a plurality of emotional-affective responses. Thirdly, while the residents could see or hear little of what was happening inside the brothels, they often sought out clues from the outside, typically from the architectural features of the brothels. Such insights, we argue, are made possible by, and highlight the possibilities of, the bringing together of urban studies and criminology.
\end{abstract}

\section{Introduction}

In 2012, [Author One] interviewed Judith, a 55 year-old resident of the seaside town of Blackpool in the North West of England. The interview was part of a project exploring the impact of brothels in the town on residents, and Judith lived in one of the red light districts. It was a wide-ranging interview and a key theme that ran through Judith's narrative, as with the other interview accounts, was the role played by the visual and the sensual in shaping the opinions and emotions of residents. $A$ memorable moment was when the interview moved on to discussing a brothel, only accessible via an alleyway, and situated above a non-sex work business. Here, Judith commented on a pair of plastic hand-shaped stickers placed on the door: "It had shiny handprints on the door, which were presumably for decoration, but it just made me think of greasy men's hands all over the women." The sight of the stickers 
seemed to trigger associations with forms of touch, clearly contributing towards, as well as being informed by, Judith's opinions about sex work and the locality.

The brief example above suggests that the visual and sensual might play important roles in how sex work within the urban environment is interpreted by those outside the industry. It is, therefore, somewhat surprising that this issue has not been explored in depth within academic research. This paper will address this lacuna in relation to brothels in Blackpool, with brothels defined here as premises that house more than one sex worker offering sexual services. A focus on brothels is important, given that street sex work has dominated academic literature, the media and public policy alike - despite indoor sex work being the more common form. That being said, scholars are beginning to investigate sex work in brothels (Sanders, 2005; Brents and Hausbeck, 2007; Cooper, 2016), residential homes (Hubbard and Prior, 2013), hotels (Kempadoo, 2002) and other spaces. Not only is there much for academics to explore about brothels and other forms of indoor sex work within cities, but there is even more that needs attention when it comes to the relationship between the visual/sensual, brothels and cities.

As well as addressing the aforementioned lacuna, the paper also has a wider purpose; it advocates for the field of urban studies to converse more with elements of criminology. In particular, it asserts that our understanding of the role of the visual and the sensual in relation to brothels in the urban environment can be greatly enhanced by engaging with ideas within the urban studies literature on sensory urbanism, as well as emerging research on aesthetic criminology. Although urban studies scholars and criminologists may study similar issues - such as sex work the bonds between urban studies and criminology are disappointingly underdeveloped. Within criminology, little has changed since Hayward (2004) noted the indifference of criminology towards studying the city. There remains very little engagement with urban theory within criminology (beyond overused references to the Chicago School). What is more, the city in criminological research remains, for the most part, a convenient site in which to conduct research and a passive backdrop to the (seemingly more important) processes, actors and institutions involved in crime and criminal justice systems. In contrast to much of the work in urban studies, the city in criminology is rarely an active object of study (Lippert and 
Walby, 2013). Relatedly, Campbell (2012) and Hayward $(2004,2012)$ point out that criminologists typically draw upon superficial understandings of space and place like the city, they are not seen as being that important in the study of crime, policing and punishment in society. This is, of course, a cause for concern.

Urban studies, however, should not escape criticism here. While it could also be argued that a number of scholars in this interdisciplinary field do engage with criminology, engagement tends to take the form of drawing on a very narrow range of texts, scholars and theories, albeit often critically - Wilson and Kelling's (1982) broken windows theory being a clear example here. Vast swathes of criminological thought remain untouched in urban studies. Bringing together sensory urbanism and aesthetic criminology, we suggest, could be a stepping stone in building new and much-needed links between criminology and urban studies.

In exploring the ways in which the senses shape residents' perceptions of brothels in Blackpool, the paper is structured as follows. It begins with an exploration, and bringing together, of the literatures on sensory urbanism and aesthetic criminology. It then provides a description of the sensory methods used. Following this, it gives an overview of the manifestations and governance of indoor sex work in Blackpool, before exploring the multi-sensory perceptions of the brothels by residents. The paper concludes by drawing out three key findings from the research project and calling for further dialogue between urban studies and criminology.

\section{Sensory urbanism}

"City life, comprising the everyday rhythms, humdrum of activities, events, routines, and other un/expected urban encounters, comes with a range of 'multi-sensory bombardment'... emanating from both human and non-human sources. Motor vehicles, horns, voices, music, nature, and tactility are but some of a wide range of possible examples that together form the sensuous character of cities. In essence, there is a superabundance of sensory affordances that are situated in the city." Low (2015, p. 295) 
We open this section by looking at three urban sociologists. The first is Kelvin Low who, in exploring the senses and urban life in the quote above, echoes a second sociologist: Georg Simmel. Writing over 100 years prior, Simmel (2012 [1903]) was interested in the sensory experiences of urban life and, in his paper 'The metropolis and mental life', he argued that urbanisation altered the social relations and senses of those living and working in the city. With vast numbers of people migrating to cities - the centre of what Simmel calls the 'money economy' - more and more people developed increasingly impersonal social relations based primarily on the buying and selling of goods. Furthermore, he reasons that the intensity of city life brings an "intensification of nervous stimulation" (ibid, p. 25, emphasis in original). A coping mechanism for many is to withdraw into oneself and develop a 'blasé attitude' towards other people and things around them.

Although Simmel is widely regarded as one of the founding figures in urban studies, in the decades following the paper few scholars followed his lead in examining the relationship between the senses and the city. Nevertheless, as the third sociologist, Michael lan Borer (2013, p. 965), has correctly noted: "[t]here has been a recent resurgence of studies depicting the experiential dimensions of city life as lived and felt through the body's five senses" (that is, hearing, sight, smell, taste and touch). It is not just sociologists involved in this revival; scholars from other disciplines are also involved. Geographers are particularly noteworthy, many of whom have been influenced by Rodaway's (1994) text Sensuous Geographies. While this book does not have an explicitly urban focus, it provides a useful starting point for understanding the geographies of sensory urbanism. Rodaway makes the case that the senses are often overlooked, but are important as they provide us "with both information about a world around us and, through their structure and the way we use them, the senses mediate that experience" (ibid, p. 4). He highlights how the senses are inherently "geographical in that they contribute to orientation in space, an awareness of spatial relationships and an appreciation of the specific qualities of different places, both currently experienced and removed in time" (ibid, p. 37). For Rodaway and others, studying sensory urbanism necessitates a geographical approach. 
The recent multi-disciplinary literature on sensory urbanism has a number of commonalities. Five are worth noting here. First is the emphasis on 'lived experience' or 'everyday life' in the city by individuals. The second is that while many of the studies explore particular senses or 'sensescapes', the authors usually note that the senses are interconnected and typically used alongside one another by individuals when experiencing urban life. Following on from this, the third commonality is that scholars have tended to note and bemoan a hegemonic hierarchy of the senses in western societies and within the academic literature. Rodaway (1994, p. 148), for instance, argues that sight and hearing are atop of the socially constructed hierarchy of the senses with touch, smell and taste beneath them. However, Rodaway reasons that, in practice, the role of each sense and the relationship between senses always varies depending on the context. Other scholars have differed slightly from Rodaway by pinpointing a fixation with sight (and not hearing) and they have sought to move away from a sole focus on sight to explore either a range of senses within the city (e.g. Urry, 2000; Shantz et al., 2008; Borer, 2013) or particular senses or sensescapes that are neither sight nor seescapes (e.g. Atkinson, 2007 on sound in the city; Henshaw, 2013 on smell in the city). This leads onto the fourth commonality in the literature, which is a focus on the regulation of the senses in the city; studies explore the ways supposedly 'inappropriate', 'discomforting' or 'out-of-place' sights and forms of touch, smell, taste and noise are governed (Cook and Whowell, 2011). The fifth and final commonality is that research has tended to concentrate on the sensory experiences of public spaces in the city.

Embodying all five of the commonalities above, Tan (2013) provides a thought-provoking account of the smellscapes and olfactory politics of Singapore through an analysis of smoking. Here, Tan begins by examining the ways in which smoking in public and smokers are framed by non-smokers and policymakers as transgressive and harmful acts and bodies. The study then moves on to explore how smokers are socially and spatially segregated from non-smokers (e.g. banished to smoking areas) and the engagement of smokers in practices of impression management and considerate smoking in the city. Sensory urbanism, as Tan rightly points out, is more than just about sight. 
Nevertheless, sight and the politics of visibility remain important and cannot be overlooked by urban scholars. This is illustrated through Cook and Whowell's (2011) analysis of the ways in which visibility and invisibility underpin the policing of public space. They note that the bodies (e.g. police officers) and technologies (e.g. CCTV cameras) doing policing are selectively visible or invisible to their targets and other audiences. Furthermore, certain individuals and groups are selectively rendered visible and invisible by those governing public space. For instance, marginalized groups such as the homeless and sex workers are often discouraged from using, or are heavily policed in, certain areas of the city (often city centres or gentrified and wealthy residential neighbourhoods). This links to Mitchell's (2003) argument that the central goal of much urban policy in an era of intensified interurban competition is to attract inward investment. The 'beautification' of public space and the removal of 'unsettling' and 'out-of-place' bodies, Mitchell argues, is an oftenused means through which to achieve this. Irrespective of whether Mitchell is too money-focused in his arguments, we can see that sight and the politics of visibility are vitally important in shaping the spaces and lived experiences of the city. These, of course, have to be understood in connection to the other senses and the ways in which they are governed.

\section{Aesthetic criminology}

In order to appreciate the nuances of aesthetic criminology, it is useful to overview its connections with and departures from the larger and more widely known body of work on visual criminology. Neither are fully-fledged theoretical or methodological approaches, but encompass instead a series of overlapping ideas and conversations. The ideas are still in development and the conversations are somewhat unresolved, but they have opened up a number of possibilities for criminologists and non-criminologists alike.

Much of the work within visual criminology appears to be motivated by a desire to "develop a more sophisticated understanding of the visual and confront the ways in which contemporary societies are saturated with images of crime" (Carrabine, 2012, p. 463). The focus of the work is typically on how offenders, criminal justice agencies and, less regularly, victims are portrayed visually. The 
images studied are often static. Examples here include documentary photography (Carrabine, 2012), court drawings (Barlow, 2016), police mugshots (Linnemann and Wall, 2013), street art and graffiti (Halsey and Young, 2006; Young, 2014), and comic books and graphic novels (Yar, 2016). Other have looked towards moving images, with studies on crime films and television programmes (e.g. Rafter, 2006; Nellis, 2009; Rafter and Brown, 2011), revenge porn (Dymock, 2016), and the selfrecording of crimes by offenders (Sandberg and Ugelvik, 2016). The tenor of much discussion within visual criminology has been about correcting stereotypical, unflattering and inaccurate reporting and portrayals of characteristics, behaviour and processes. However, in recent years, this has started to change, with a move from criminologists calling for people to ignore or be wary of images (as it might impede their understanding of the 'reality' of crime and criminal justice) to an appreciation that our world is infused with the chatter from multi-media outlets.

Visual criminology encourages us, then, to think about the impact of the image or object on us as either active subjects (as offenders, victims or criminal justice agency professionals) or passive subjects (as part of the non-offending population); it provokes us to reflect on power relations of the criminal image and object. The power relations of images not only refer to the ability of the state and other bodies to shape access to images of crime and criminal justice, but also the ways in which we produce and consume (and are encouraged to produce and consume) images. Because much of what interests criminologists and the public about crime and punishment is "secretive and socially invisible" (Garland, 1990, p. 186), and while crime television and film does to some extent "make visible punishment that would otherwise be conducted in secret" (Wilson and O'Sullivan, 2005 , p. 473), the 'criminal' image has a "power of imagining rather than imaging" (Valier, 2004, p. 251). This is to say, that images have an impact on what we think we know about crime, and how we affectively and emotionally react to both our individual and collective (whether these be social or institutional) notions of offending.

In a thought-provoking paper, Alison Young (2014) draws on many of the above ideas from visual criminology but calls instead for an understanding of "criminological aesthetics" (p. 162). Young outlines her argument through a case 
study exploring the different interpretations and reactions by criminal justice agencies to an unauthorized 'painting out' of an advertising panel in a Melbourne bus stop. Here, she suggests that scholars need to avoid object-centred analyses - a tendency within some visual criminology work. Aesthetic criminology, instead, favours exploration of the ways in which "meaning derives from the affective nature of the spectator's encounter with the image" (2014, p. 161, emphasis in original; see also Halsey and Young, 2006). The example of the interpretations of, and responses to, the painting out captures Young's nuanced point that an aesthetic criminology should not be about describing static images; instead it needs to explore "the processes of interpretive contestation governing our encounter with the image" (Young, 2014, p. 172). A key aspect of the encounter for Young is affect. That is, the embodied and physiological reaction to an image, object or event: something that the body feels before it deciphers it and expresses it as an emotion, or a social construct more easily understood by others. Although often difficult to express in words, affect is an important consideration in the study of criminological images.

The work on aesthetic criminology by Young (2014) and Millie (2016) also commendably take the city as an important object of study, but the city tends to be hidden in the background in most of the visual criminology literature. The literatures on aesthetic and visual criminology have two other weaknesses, both of which can be addressed. Firstly, they rely too much on two-dimensional images to study and would benefit by exploring three-dimensional objects and places as well. One such three-dimensional example is a building; aesthetic criminology in particular can help us better understand the production, iconography, use and perception of a variety of buildings that both criminologists and urban scholars are interested in, such as police stations, prisons, or 'illicit' premises such as brothels. Such a focus would build on Millie's (2012) earlier exploratory research on how the architecture styles of police stations shape people's perceptions of the police station and what happens inside, and of policing more generally. It would also strike a chord with the expanding work on the cultural geographies of architecture which has explored issues of power and inequality in relation to the built environment, as well as the dynamic ways in which people inhabit, maintain, make meaning out of, and are shaped in some way by, buildings (e.g. Lees, 2001; Kraftl and Adey, 2008; Kraftl, 2010). A second issue with the literature is its limited focus on the senses beyond the visual. Millie (2016) has 
hinted at the value of exploring the senses when, taking Young's ideas further, he calls for "an aesthetic criminology... that includes consideration of the visual, but also broader sensory, affective and emotive experience" (p. 2, emphasis added). However, the senses beyond the visual are not explored in much depth beyond this statement.

It is possible and beneficial, therefore, to develop a more nuanced holistic approach towards the study of the senses, liminality and the city. This approach takes from sensory urbanism an emphasis on the lived experience and spatial practices of those inhabiting and working in the city, as well as a commitment to exploring how the senses - including, but not limited to, sight - shape and mediate these experiences and practices. This can work alongside an emphasis, taken from aesthetic criminology, on the criminalisation of sights (and sounds, tastes, smells and forms of touch), the production of meaning from aesthetic (and sensory) encounters, and the roles of emotion, affect and power within this production.

\section{Utilising a sensory methodology}

In recent years, visual methodologies and methods have become increasingly popular across the social sciences (e.g. O'Neill and Hubbard, 2010; Carrabine, 2015; Rose, 2016), and in particular by scholars researching the sex industry (e.g. Desyllas, 2013; Sanders and Hardy, 2014). The research project on which this paper is based, however, utilized a sensory rather than a visual methodology as it aligns better with the ontological underpinnings of sensory urbanism; it is attentive to the multi-sensoriality of the urban experience (Low, 2015; Pink, 2011, 2015; Phillips 2015). Sensory methodologies also have the potential to highlight the unexpected, invisible and unspoken aspects of life in the city (Pink, 2015).

The empirical examples discussed in this paper draw upon data collected as part of [Author One]'s (2014) doctoral thesis exploring the impact of brothels in Blackpool on residents. With regard to methods, the project involved a combination of participant observations and interviews. Participant observations were conducted over the course of one year (2011-2012) around the two main clusters of brothels in Blackpool - referred to in this paper as the Cookson Street and Central Drive areas. 
A 'resident at leisure' dynamic was adopted whereby the researcher spent time walking and driving around the areas at systematic time intervals (morning and night), using local facilities. As part of this, the visual and sensual aspects of the brothels and the surrounding spaces were carefully observed and recorded in a research diary. Here, observations about smells, noise and aesthetics were noted, with careful attention paid to the architectural features of the brothels. Semistructured interviews were conducted with 53 residents living and/or working in nonsex work premises in or nearby (<0.5 miles) to the two locations. Interviews were also conducted with three sex workers, three police officers and two Blackpool Council officers. Interviews were more conservative than some sensory interview techniques suggested by Pink (2015, pp. 73-93). However, through verbal communication primarily, the interviews explored the sensory perceptions of brothels by the residents, and the sensory aspects of running, working in and governing the brothels (with the sex workers, police and council officers). In this paper, we will refer to a number of the interviews conducted. The interview participants have been given pseudonyms, while the brothels have not.

\section{Manifestations and governance of sex work in Blackpool}

Blackpool is a small town in the North West of England, with a population of around 140,000 (Lancashire County Council, 2015). According to the Index of Multiple Deprivation (2015), Blackpool contains 15 neighbourhoods that are highly deprived in six or all seven of the criteria - two of which are where the main brothel clusters are located. The population of the town is $96.7 \%$ white (JSNA, 2011).

The sex industry in Blackpool comprises of street sex work, brothels (mainly described as massage parlours locally), private flats, independent escorts, lap dancing venues and sex shops. The brothels are mainly clustered in two areas: Central Drive and Cookson Street and their adjacent streets. These can be found on the outskirts of Blackpool's central business district. Both locations have mixed land uses, with several non-sex work premises and residences surrounding them. Many of the surrounding residences are rented properties and largely comprise of flats next to or above shops. Central Drive and Cookson Street are main driving thoroughfares in and out of the central business district, and do experience 
continuous traffic and footfall during the day, but become quieter in the early evening. There are two main differences between the two areas in the appearance and type of sex work present. First, while both have off-street sex work, on-street prostitution takes place in Central Drive but not Cookson Street. Second, the brothels in the Cookson Street area are higher in numbers, and are more publicly visible on-street than Central Drive. Brothels on Central Drive mainly have backalley entrances and are above other non-sex work premises, whereas Cookson Street brothels occupy the whole building with on-street entrances.

Blackpool's brothels are not licensed by the local council, although the council and police are generally tolerant towards brothels and sex work in the city. As we shall note, the police and council intervene in certain matters but on the whole, as one Blackpool Council officer interviewed stated, they operate a "turn a blind eye... until too many people complain" strategy. Such an approach is the result of a mixture of local discretion and the national legal system in which it is embedded. In England and Wales, the exchange of sex for payment between consenting adults is legal, although a number of activities related to sex work are illegal. These include: the operating of a brothel, soliciting, kerb crawling, and paying for sex with someone who is either under 18 or coerced into sex work (see Sanders, 2012). In the majority of towns and cities across England and Wales, the primary focus of the police has been on-street sex work. Here, street sex work is often equated with being a predominantly visual public nuisance. Sex workers, their clients and the detritus of sex work, such as used condoms and needles, are framed as sights which passersby and neighbouring residents might find discomforting or offensive (Kantola and Squires, 2004). The noise of sex workers and clients is also sometimes deemed to be anti-social (Scoular et al., 2007).

Where sex work is more private and hidden within brothels, there has been less concern from most police forces nationwide about the visual and aural aspects of indoor sex work. Despite this, local authorities typically still make restrictive decisions about the location of sex premises in a precautionary (moral) manner, designed to mitigate the presumed offence taken by residential communities - often with limited or unsubstantiated impact evidence from such communities (Prior and Crofts, 2012; Prior et al., 2013). To borrow Valverde's (2010) phrase, local 
authorities such as those in Blackpool have engaged in 'optical governance' tactics, effectively policing 'the aesthetic'. These are based on what should or should not be seen on or around the premises, how vibrant or prominent certain characteristics are, and who can or should see them. Governing the visibility of sex work is underpinned by a moral discourse of protecting the sacredness and innocence of family-orientated spaces. Indeed, it was noted in several of the interviews with police officers and Blackpool Council officers that a key objective of Blackpool's sex work regulation was to protect children from harm (although harm could not be defined conclusively). Here, it is assumed that exposure to certain 'adult' aesthetics can oversexualize children.

In part influenced by radical feminist ideas around sex work - where sex work is seen as being inherently violent, abusive and coercive - police forces and other agencies have been increasingly focused on the sex worker as a victim of sex work (see Raymond, 2013 for an illustration of radical feminist thought on prostitution). Touch plays an important part here; not so much in terms of the tactile intimacy of sex work, but the physical violence that sex workers can experience from clients, third parties and other individuals. Authorities in Blackpool exhibited concern about violence within the brothels, and a nominated police officer is responsible for monitoring the sex workers' welfare and the surrounding residences, but did not indicate that violence was a regular occurrence. Smell and taste have played little role in the governance of sex work in Blackpool. Loud noise - such as sex workers having arguments with clients stood outside the brothels - was mentioned in the interviews as something that has triggered conversations between authorities and the sex workers in the brothels. It is clear, therefore, that governing sex work is predominantly focused on shaping the visual landscape of the city, but the authorities also pay some attention to other sensory aspects of sex work (notably touch and noise).

\section{Sensory perceptions of brothels by residents}

A key finding of the research is that the residents interviewed tended to focus on the visual aspects of brothels rather than other sensory aspects. However, this is not to say that the senses beyond sight were neither important nor interconnected. The 
example of Judith, detailed in the introduction to this paper, illustrates this point. Here, the sight of plastic hand-shaped stickers placed on the door of a brothel evoked in Judith mental images of men touching women. This example shows that the visual can evoke wider sensory imaginations and emotions. Given the predominance of the visual in the perception of brothels by residents, we shall focus on the visual in this section. In particular, we will concentrate on a small number of recurring architectural features of the brothels whose aesthetics were widely commented upon in the interviews with residents, brothel owners, and the authorities. These are lights, signage, doors and windows.

\section{Lights}

Echoing other retail premises in the city, lighting is a prominent architectural feature of the Blackpool brothels. At the time of the research, all brothels had some sort of light burning. Some premises had the lights switched on at certain times while others had theirs on 24 hours a day. The colours of the light would usually be white, neon blue, pink or (less often) red - the latter being a colour often associated with sex work. There was variation in the types of lighting also, ranging from neon bar lights to those resembling Christmas fairy lights, table lamps and illuminated text. Both the brothel owners and the authorities believe that the lights influence the way in which others - residents and potential customers - perceive the premises. This resonates with the literature on lighting in retail environments, which posits that emotions, ambience and consumption patterns of shoppers can be altered by the form of lighting deployed inside and outside stores (e.g. Custers et al., 2012). Indeed, as Box 1 highlights, the lights of the Blackpool brothels were a source of contention with the authorities taking up a 'plain white light' purification campaign. 
Box 1: Extracts from interviews discussing lighting

"They aren't allowed to have neon coloured lights anymore; they have to be plain white. We've told them they need to be more inconspicuous" (Police Officer)

"Hopefully the reduction in the more obvious coloured lighting will make it less obvious to the public" (Council Officer)

"It's so unfair that we've had to take our lights down and our sign - [another brothel called] Jade's has the name lit up and no-one says anything" (Cindy, brothel owner)

White lights were seen by the authorities as being more conspicuous, less garish and less unsettling for passers-by. This feeds into the wider societal association between the colour white and purity. Cindy, a brothel owner in Central Drive quoted above, was also asked by the council to change the type of the lighting used in one of the internal windows of the brothel, from a lamp with an image of a woman on it to a plain white bar - despite her concern that the alterations would reduce the number of new clients. She noted in the interview that she adopted a Victorian style erotic table lamp in the window instead, in order to indicate to potential clients that they were still open and to give a "good impression" to residents and potential customers.

Sometimes the lighting was interpreted by residents in ways that the brothels were not intending. This point resonates with Kraftl's (2010) observation that while buildings are often designed to produce particular affective responses from users, these are not always realized in practice. The 'Christmas lighting' style adopted by one Blackpool brothel, for instance, was referred to by one interviewee as "barbed wire" (Carl, 24, resident in Cookson Street area). Its presence reminded another resident of "that Liam Neeson film [Taken] where his daughter was kidnapped and sold into the sex trade" (Hayley, 26, resident in Cookson Street area). This speaks to the often-occurring conflation between trafficking and sex work - several residents 
mentioned 'trafficked girls' in interviews - and also highlights the role of the media in shaping public perceptions of sex work. The theme of imprisonment also came through in discussions about the non-illuminated parts of the brothels and led to speculation as to what occurs in these spaces. Paul (58), a resident near Cookson Street, stated for instance that "blacked out windows don't send the message that the girls are being looked after; [they] aren't as reassuring". We will return to the issues of windows and imprisonment later.

\section{Signage}

There was a notable variation in the signage between the two areas in Blackpool. Signage is considerably more prominent in Cookson Street than Central Drive, where brothels are more conspicuous. Signage in both areas would change regularly, often due to changes in occupation and ownership, and without planning permission. Most of the signs had a degree of ambiguity about the nature of the business inside, although some were more explicit (in both senses) than others. None of the premises stated outright on their façade that they sell sex but many were suggestive in terms of their lighting (as noted previously), their business name and imagery used. In terms of business names, Twilight Babes on Cookson Street, for instance, opted for more sexually-suggestive terminology and imagery on the front of its premises (Figure 1). Thai Paradise in the Cookson Street area, meanwhile, drew on the stereotypical geographical association between Thailand and sex work. Others such as Natalie's Sauna (Cookson Street) and Jade's (Central Drive) opted for the 'name' (or pseudonym) of the brothel owner. In contrast, some brothels especially those that, according to the local Council, temporarily 'pop-up' - only featured a street name and number and not a business name. The ambiguity of the signs, echoing other localities in the UK, was based on an unwritten understanding between the brothels and the authorities that their signage could be suggestive but not explicit. 


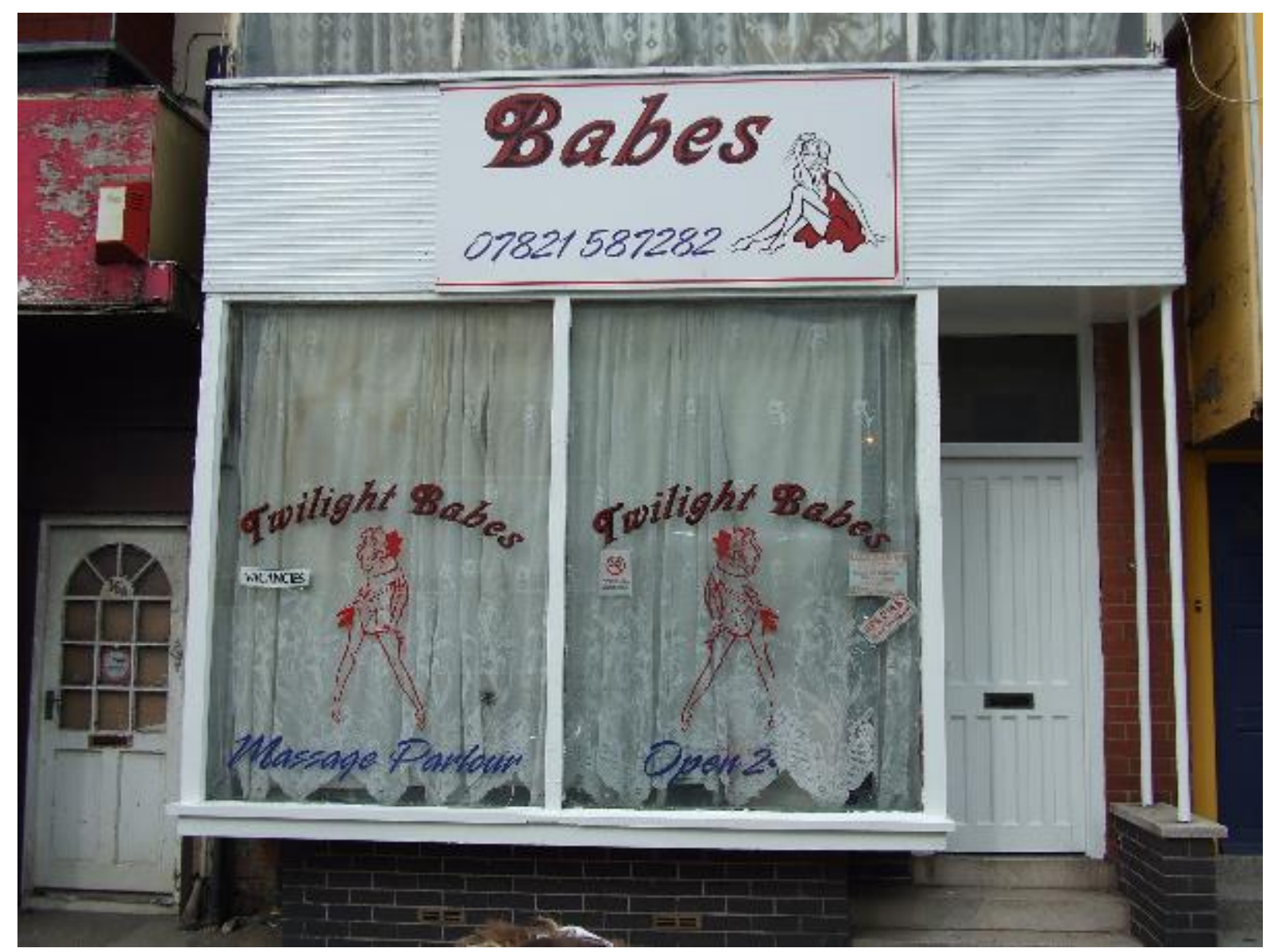

Figure 1 Twilight Babes, Cookson Street

The signage was often a focal point of discussion from residents. Many residents demonstrated some unhappiness at the ambiguous nature of the signage and some of the misunderstandings that could result because of this. Pat (64), a worker in the Cookson Street area, for instance, reasoned:

"That one next to us, Thai Paradise, it's dangerous actually as some customers of ours went in there thinking it was a Thai restaurant. What if some youngsters did that too? We can sometimes smell their cooking too, so it's an easy mistake to make". 
Here, Pat speaks to a wider fear associated with sex work: that it could shock and upset unknowing passers-by and children in particular. Furthermore, through linking sight and smell, Pat also points to the way sight works alongside other senses in shaping our perceptions of places. For others, though, ambiguous signage was not necessarily a problem; it was less conspicuous, but still managed to discreetly attract those who knew where to go (e.g. through prior visits or understandings of the visual codes).

The use of external images varied between brothels. Many had no images, in particular those in Central Drive. One brothel near Cookson Street had a banner saying 'you are welcome' and a photograph of a woman underneath the text. However, the use of photographs on the building façades was limited to this one example; those using images typically opted for cartoons of voluptuous, seductively posed women. Tabu on Cookson Street, for instance, has an illustration of woman with the words 'Hello Boys! XXX PLEASE COME INSIDE' written on a door inside the porch visible to those passing by. Discussing Tabu, Max (22), who works nearby, mused that "[t]he pictures and that are self-explanatory, especially that "hello boys" one - no mistaking what that is saying". Here, the images of women on the exterior of Tabu and other brothels are deployed as exaggerated 'previews' of what you might see and touch if you step inside. Several residents, however, did not like suggestive imagery being used on the exterior of the premises. This was deemed to be too inappropriate - that is, too sexualising and too conspicuous - to be displayed in public space.

In addition to business names and images, a number of brothels in the Cookson Street area displayed phone numbers and a few listed business hours but most did not. For Paul (58), a resident in the Cookson Street area, these aspects created an impression of professionalism and of good working conditions:

"I think the Natalie's Sauna one looks more like a business, with the opening hours on the side and the banner, as opposed to Tabu with the barbed wire and blacked-out window. It sends a message that the women are being looked after and perhaps the business is cleaner." 
The example of Paul here speaks to a recurring theme in the interviews that the external façade of the brothels can give visual clues about the mysterious and secretive goings-on inside the premises; something that the residents would often speculate on in, and away from, the interviews. None of the residents interviewed either directly stated, or hinted, that they had actually entered any of the brothels, but some did discuss browsing the brothel websites. Their limited knowledge of the interiors of the brothels meant, therefore, that they had to rely on the exteriors of the brothels for clues as to what was happening inside.

\section{Doors and windows}

Alongside lights and signage, doors and windows were other important architectural features that shaped the way residents thought about the brothels. These acted as sensory clues, conduits and barriers for residents attempting to gain an insight into the activities inside. The doors and windows were a source of intrigue and a frustration. For some, they were also welcomed screens and containers hiding what should not be seen or heard in public space.

Most of the Cookson Street area brothels tended to have an exterior door that was positioned on-street, with a short corridor leading to an interior door that has an intercom (see Figure 2). In contrast, most of the Central Drive brothel entrances were in alleyways behind the main thoroughfare and up some stairs (see Figure 3), with one brothel doorway being on-street but slightly below street-level. In both areas, it was not possible to see much, if any, of the interior of the brothels from outside. In both Central Drive and Cookson Street, the view inwards was often obscured by curtains, net curtains or blinds and these were never removed during the periods of observation. Transparency, in short, was deemed undesirable by those working in the brothels. Nevertheless, the use of an exterior door (typically open during working hours) and locked interior door in the Cookson Street brothels provided a small insight into the premise from the outside. Although it was only a view of the corridor, such a layout was used to give the impression that the brothel was welcoming and secure, public and private. The corridor also acted as a space of curiosity and invitation for those passing by. Importantly, these were not purposebuilt brothels but buildings having relatively inexpensive and creative alterations 
done to them, in order to enhance privacy and send out a visual message to potential clients that they would not be on public view when inside.

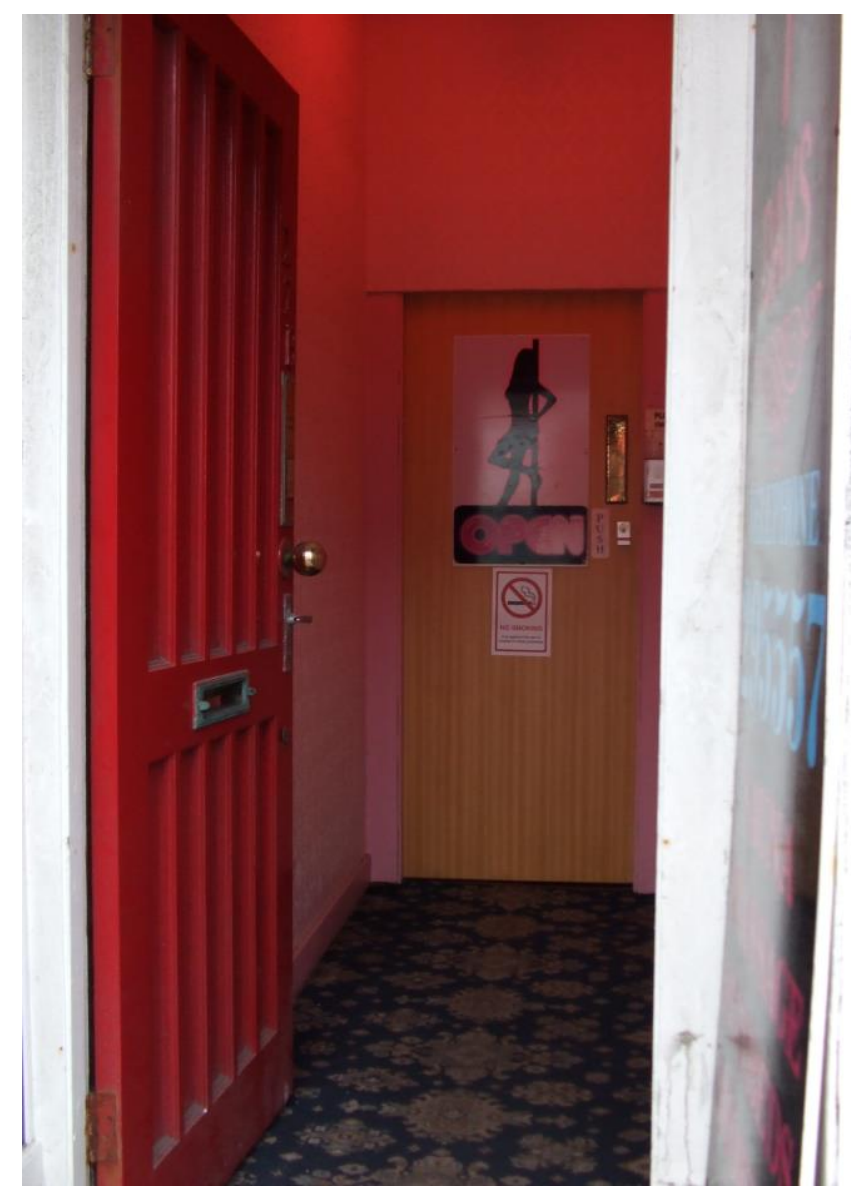

Figure 2 Example of a Cookson Street brothel entrance 


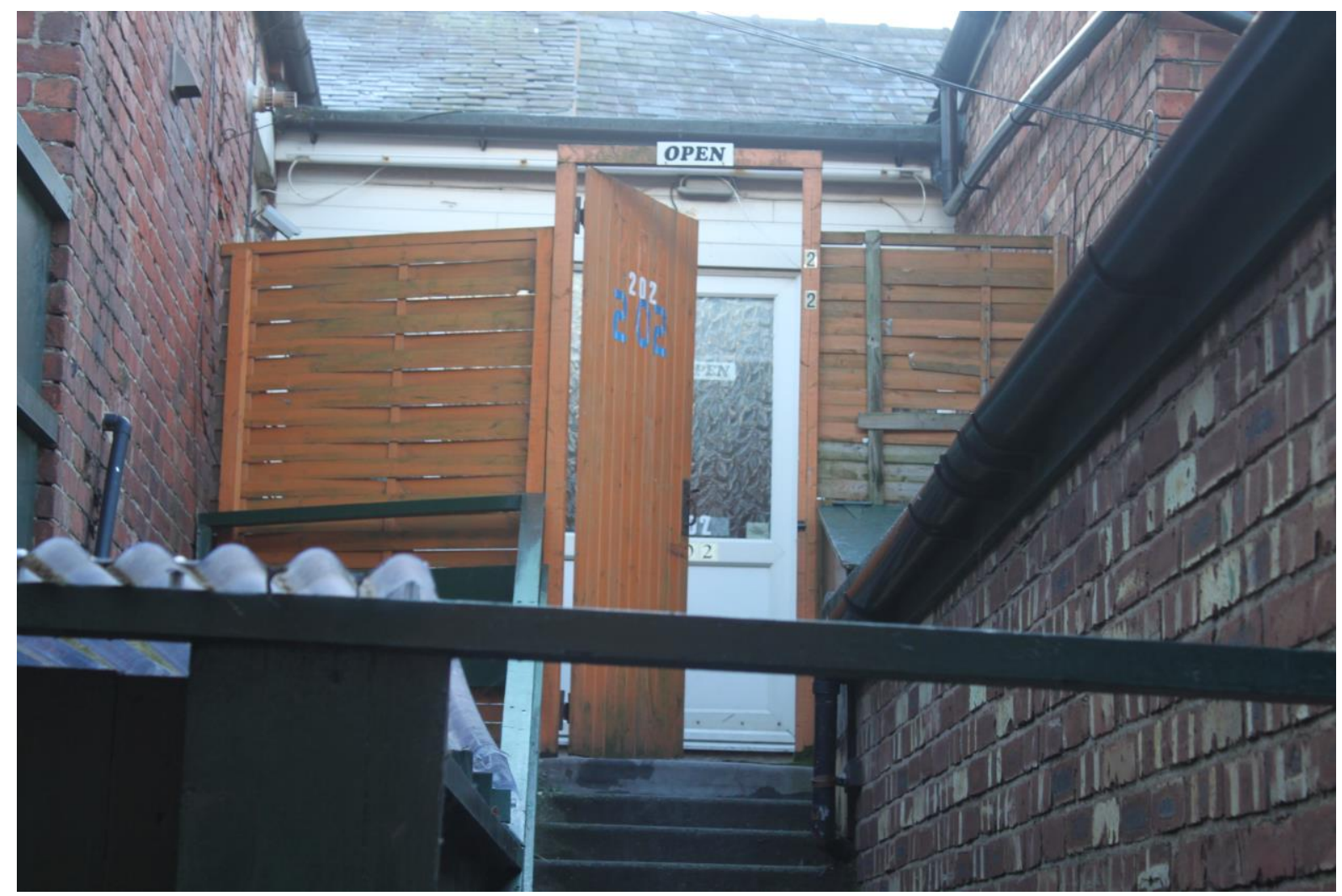

Figure 3 Example of a Central Drive brothel entrance

As noted above, the accessibility of the brothels on Central Drive was typically via alleyway entrances and not the main road. This had the positive effect of reducing the often unwanted 'public gaze' on those entering the brothels. However, access via alleyway entrances did prompt speculation from one resident of Central Drive, Mary (25), about what happens inside:

"It has a back alley entrance, very confined and isolated, away from the main street. You automatically get the impression that they are doing something wrong."

The usually closed doors and windows of brothels in both areas meant that relatively little noise (e.g. voices, music) or smell emanating from the brothels 'escaped', with the exception of the smell of Thai food from Thai Paradise mentioned earlier. This is in stark contrast to many (legal) retail outlets who seek to entice 
customers through certain smells and sounds (Soars, 2009). Some residents welcomed the relatively self-contained nature of the brothels, such as Brian (35), a worker on Cookson Street who said:

"Well, the images are suggestive but at least there aren't actual women hanging around outside which would make it more real. The door protects the public from knowing what is happening, from seeing the reality really".

While some residents were keen for the activities of the brothels to be hidden away inside, many would still speculate on what was happening inside, using the architectural features of the brothels as indicators. The safety of those working inside was an issue that some residents pondered over from a distance using these visual indicators. For instance, another resident who lived near Central Drive, June (55), mused on the intercom of one brothel:

“The intercom suggests that they don't just let every Tom, Dick or Harry in. I guess it's a comfort knowing that there is some vetting before a client is allowed in".

Another brothel was subject to much speculation. Situated on Central Drive, it had an entrance below street-level on the main road. It also had no clear telephone number or opening hours on the façade and no internet presence. As displayed in Box 2, for some of those interviewed its relative secrecy and unusual architecture evoked sinister and even dangerous images.

Box 2: Comments from residents on specific Central Drive brothel

"That one on Central Drive with the pink door has a weird contrast of images - it's bright pink but has an iron gate outside like the entrance to a prison... [it] makes me shudder" (Bruce, 38, worker on Cookson Street)

"It looks like the entrance to a basement, I can't help but think there is some poor girl trapped down there" (Anne, 40, worker on Central Drive) 
The quotes in Box 2 speak once more to the theme of imprisonment, a sense that these premises were holding women captive. Once again, this echoes wider media portrayals of sex work, but it goes against the reality that very few incidents of trafficking and underage sex work have been reported in the city (interview, Police Officer).

\section{Emotional-affective responses and creative observations}

The brothels in Blackpool evoked a variety of emotional-affective responses from residents. It is worth reflecting here on these as well as those responses and feelings that went unspoken. In his research on sex work in other western cities, Phil Hubbard has regularly framed societal attitudes towards sex work within the binary emotions of disgust and desire, "so that the prostitute is both repudiated and desired" (Hubbard, 2004, p. 677). The interviewees in Blackpool pointed to slightly different emotional-affective responses; their talk and bodily demeanour pointed to feelings of discomfort and unease for some interviewees and ambivalence for others. However, it is important to acknowledge here that desire (and perhaps disgust) may have been considered unspeakable by some of those being interviewed. Another recurring response was intrigue; not necessarily sexual intrigue, but in terms of wondering what was happening inside the brothels close to where the interviewees lived and/or worked. Bruce's talk of shuddering when viewing the 'prison' brothel in Box 2 also suggested that the brothels could evoke bodily sensations in residents other than those that some of the brothels wish to impart (such as those associated with sexual arousal).

The ways in which residents watched the brothels are also important to consider. As Box 3 demonstrates, the residents made judgements about the working practices inside the premises based on the inanimate architectural objects outside, as well as any movement or noise spotted within or nearby. They also posed questions to themselves and made judgements based on any changes to the exterior of the brothels. Particularly in Cookson Street, residents often engaged in creative and often playful practices to watch and listen. They often tried to observe 
at a distance and mask their actions, to pretend they are not staring or listening too intently, because they did not want to be perceived as being either intrusive neighbours or customers.

Box 3: Resident behaviours while encountering the brothels

"I sent Stu to look into the window of that one the other day. It used to have a sign saying 'Red Hot Blonde' and 'pussycat' in the window... now 'The Gaff' sign has been moved and it's just a red curtain. You wonder why they change. Have they been caught?" (Marie, 24, resident in Cookson Street area)

"I never know what that one's going to be called tomorrow [referring to Dolly Babes on Cookson Street]. My husband is a taxi driver too and he points a different one out every time. You can't help but look at it from then on, even if it just looks like an ordinary house! I only do it when I'm in the car though!" (Pat, 64, worker in Cookson Street area)

"I'll always go outside on my break and people-watch. It definitely makes my breaks more interesting. I'll strategically stand with my cigarette so I can see everything. It's different every day" (Jim, 52, worker on Cookson Street)

There are faint similarities between the interviewees and Walter Benjamin's (1999) flâneur here; a man who strolls voyeuristically through the city, simultaneously detached from and enthralled by the vibrancy of his surroundings. $\mathrm{He}$, like the residents of Blackpool, was an amateur detective of sorts. Yet unlike the flâneur, the intrigued residents were neither solely men nor were they predominately on the move when observing. Indeed, Jim in the quote above talked about observing while standing outside on a cigarette break, and Mandy (53) described how she would watch the brothels through the window while at work (but would avoid "gawping" if customers came into her building). For Jim and Mandy, observing the sexual Other became routinized everyday performance. 


\section{Conclusion}

This paper opened by calling for closer dialogue between urban studies and criminology: two fields of study that have, for too long, tended to work in isolation. Here we have sought to demonstrate how certain conceptual and theoretical ideas from urban studies (on sensory urbanism) and criminology (on aesthetic criminology) can productively inform and aid each other. Indeed, the paper has suggested a holistic framework, taking ideas from sensory urbanism and aesthetic criminology, which can enhance our understanding of the multi-sensory encounters and perceptions of brothels by surrounding residents. Such a framework emphasizes the lived experience and spatial practices of those inhabiting the city, multi-sensoriality, the production of meaning from sensory encounters, and the roles of emotion, affect and power within this production.

Three key observations from the case study of residential perceptions of brothels in Blackpool are useful to note here. First, while the visual appears to have the most influence over the governance of sex work in Blackpool as well as the perceptions of residents, touch and smell (and their interaction with the visual) also play small but important roles. Second, residential perceptions of sex work and brothels are linked to, and encompass, a plurality of emotional-affective responses, many of which were not intended by those decorating the brothel exteriors. Third, residents were active and creative in the production of meaning from the brothels. Although their understandings of brothels and sex work were shaped by the ambiguity of the brothels and the media, they also emerged out of the residents' curious searches for, and interpretation of, clues often drawn from the external façade of the brothels. Clues they hoped would give them an insight into what was happening inside. We can see, therefore, that there was significant degree of agency in their observations and interpretations. Together the findings from this research project would suggest that Agustin (2005) is correct in calling for a more comprehensive cultural analysis of sex work in the city, moving away from purely moral or legal concerns and exploring its intersections with aesthetics, art and everyday life. Making sense of the visual and sensual dimensions of sex work should be central to this research agenda. 
Of course, in making the case for a closer dialogue between urban studies and criminology, we have focused on relatively small parts from both fields: sensory urbanism on the one hand and aesthetic criminology on the other. There are countless other empirical insights, conceptual ideas and methodological innovations that can be shared and co-produced between urban studies and criminology. Future dialogue and research, therefore, is of paramount importance. Working together can result in increasingly nuanced understandings of sex work in the city as well as many other aspects of urban criminological life.

\section{References}

Augustin, L. (2005) The cultural study of commercial sex. Sexualities 8.5, 618-631.

Atkinson, R. (2007) Ecology of sound: the sonic order of urban space. Urban Studies 44.10, 1905-1917.

Barlow, C. (2016) Sketching women in court: the visual construction of co-accused women in court drawings. Feminist Legal Studies 24.2, 169-192.

Benjamin, W. (1999) The arcades project. New York, Belknap Press

Borer, M.I. (2013) Being in the city: the sociology of urban experiences. Sociology Compass 7.11, 965-983.

Brents, B.G. and K. Hausbeck (2007) Marketing sex: US legal brothels and late capitalist consumption. Sexualities 10.4, 425-439. 
Carrabine, E. (2012) Just images: aesthetics, ethics and visual criminology. British Journal of Criminology 52.3, 463-489.

Carrabine, E. (2015) Visual criminology: history, theory, and method. In H. Copes and J.M. Miller, (ed.) The Routledge handbook of qualitative criminology. Routledge, London.

Campbell, E. (2012) Landscapes of performance: stalking as choreography. Environment and Planning D: Society and Space 30.3, 400-417.

Cook, I.R. and M. Whowell (2011) Visibility and the policing of public space. Geography Compass 5.8, 610-622.

Cooper, E. (2016) "It's better than daytime television": questioning the socio-spatial impacts of massage parlours on residential communities. Sexualities 19.5-6, 547566.

Custers, P.J.M., Y.A.W. de Kort, W.A. IJsselsteijn and M.E. de Kruiff (2010) Lighting in retail environments: atmosphere perception in the real world. Lighting Research and Technology 40.3, 331-343.

Desyllas, M.C. (2013) Using photovoice with sex workers: the power of art, agency and resistance. Qualitative Social Work 13.4, 477-501. 
Dymock, A. (2016) Prurience, punishment and the image: reading 'law-and-order pornography'. Theoretical Criminology (early online) doi:

$10.1177 / 1362480616630043$

Garland, D. (1990) Punishment and modern society. Clarendon, Oxford.

Halsey, M. and A. Young (2006) "Our desires are ungovernable": writing graffiti in urban space. Theoretical Criminology 10.3, 275-306.

Hayward, K.J. (2004) City limits: crime, consumer culture and the urban experience. GlassHouse, London.

Hayward, K.J. (2012) Five spaces of cultural criminology. British Journal of Criminology 52.3, 441-462.

Henshaw, V. (2013) Urban smellscapes: understanding and designing city smell environments. Routledge, London.

Hubbard, P. (2004) Revenge and injustice in the neoliberal city: uncovering masculinist agendas. Antipode 36.4, 665-686.

Hubbard, P. and J. Prior (2013) Out of sight, out of mind? Prostitution policy and the health, well-being and safety of home-based sex workers. Critical Social Policy 33.1, 140-159. 
Joint Strategic Needs Assessment (JSNA) (2011) [WWW document]

http://www.blackpooljsna.org.uk/Home.aspx (accessed 09 November 2015)

Kantola, J. and J. Squires (2004) Discourses surrounding prostitution policies in the UK. European Journal of Women's Studies 11.1, 77-101.

Kempadoo, K. (2002) Freelancers, temporary wives and beach boys: researching sex work in the Caribbean. Feminist Review 67.1, 39-62.

Kraftl, P. (2010) Geographies of architecture: the multiple lives of buildings. Geography Compass 4.5, 402-415.

Kraftl, P. and P. Adey (2008) Architecture/affect/inhabitation: geographies of being-in buildings. Annals of the Associations of American Geographers 98.1, 213-231

Lees, L. (2001) Towards a critical geography of architecture: the case of an Ersatz Colosseum. Cultural Geographies 8.1, 51-86.

Linnemann, T. and T. Wall (2013) "This is your face on meth": the punitive spectacle of 'white trash' in the rural war on drugs. Theoretical Criminology 17.3, 315-334.

Lippert, R.K. and K. Walby (2013) Introduction: how the world's cities are policed, regulated, and securitized. In R.K. Lippert and K. Walby (eds.) Policing cities: urban securitization and regulation in a twenty-first century world. Routledge, London. 
Low, K.E.Y. (2015) The sensuous city: sensory methodologies in urban ethnographic research. Ethnography 16.3, 295-312.

Millie, A. (2012) Police stations, architecture and public reassurance. British Journal of Criminology 52.6, 1092-1112.

Millie, A. (2016) Urban interventionism as a challenge to aesthetic order: towards an aesthetic criminology. Crime Media Culture (early online) doi:

$10.1177 / 1741659016631609$.

Mitchell, D. (2003) The right to the city: social justice and the fight for public space. Guildford, London.

Nellis, M. (2009) The aesthetics of redemption: released prisoners in American film and literature. Theoretical Criminology 13.1, 129-146.

O'Neill, M. and Hubbard, P. (2010) Walking, sensing, belonging: ethno-mimesis as performative praxis. Visual Studies 25.1, 46-58.

Phillips, R. (2015) Playful and multi-sensory fieldwork: seeing, hearing and touching New York. Journal of Geography in Higher Education 39.4, 617-629.

Pink, S. (2011) A multisensory approach to visual methods. In R. Margolis and L. Pauwels (eds.) The Sage handbook of visual research methods. Sage, London.

Pink, S. (2015) Doing sensory ethnography, 2nd edition. Sage, London. 
Prior, J. and Crofts, P. (2012) Effects of sex premises on neighbourhoods: residents, local planning and the geographies of a controversial land use. New Zealand Geographer 68.2,130-140

Prior, J., Crofts, P., Hubbard, P. (2013) Planning, law and sexuality: hiding immorality in plain view. Geographical Research 51.4, 354-363

Rafter, N. (2006) Shots in the mirror: crime films and society, 2nd edition. Oxford University Press, Oxford.

Rafter, N. and M. Brown (2011) Criminology goes to the movies: crime theory and popular culture. New York University Press, New York, NY.

Raymond, J. (2013) Not a choice, not a job: exposing the myths about prostitution and the global sex trade. Potomac, Washington DC.

Rodaway, P. (1994) Sensuous geographies: body, sense and place. Routledge, London.

Rose, G. (2016) Visual methodologies, 4th edition. Sage, London.

Sanders, T. (2005) Sex work: a risky business. Willan, Cullompton.

Sanders, T. (2012) Policing commercial 'sex work' in England and Wales. In P. Johnson and D. Dalton (eds.) Policing sex. Routledge, London. 
Sandberg, S. and T. Ugelvik (2016) Why do offenders tape their crimes? Crime and punishment in the age of the selfie. British Journal of Criminology (early online) doi: 10.1093/bjc/azw056.

Sanders, T. and K. Hardy (2014) Flexible workers: labour, regulation and the political economy of the stripping industry. Routledge, London.

Scoular, J., J. Pitcher, R. Campbell, P. Hubbard and M. O'Neill (2007) What's antisocial about sex work? The changing representation of prostitution's incivility. Community Safety Journal 6.1, 11-17.

Shantz, B.-M., R. Kearns and D. Collins (2008) Intolerance for noise and disorder: questioning the 'publicness' of Auckland's Queen Street. Urban Policy and Research $26.1,39-55$.

Simmel, G. (2012 [1903]) The metropolis and mental life. In J. Lin and C. Mele (eds.) The urban sociology reader. Routledge, London.

Soars, B. (2009) Driving sales through shoppers' sense of sound, sight, smell and touch. International Journal of Retail and Distribution Management 37.3, 286-298.

Tan, Q.H. (2013) Smell in the city: smoking and olfactory politics. Urban Studies $50.1,55-71$.

Urry, J. (2000) City life and the senses. In G. Bridge and S. Watson (eds.) A companion to the city. Blackwell, Oxford. 
Valier, C. (2004) Introduction: the power to punish and the power of the image. Punishment and Society 6.3, 251-254.

Valverde, M. (2010) Seeing like a city: the dialectic of modern and premodern ways of seeing in urban governance. Law and Society Review 45, 277-312

Wilson, D. and S. O'Sullivan (2005) Re-theorising the penal reform functions of the prison film: revelation, humanisation, empathy and benchmarking. Theoretical Criminology 9.4, 471-91.

Wilson, J.Q. and G.L. Kelling (1982) Broken windows. Atlantic Monthly 249.3, 29-38. Yar, M. (2016) Imaginaries of crime, fantasies of justice: popular criminology and the figure of the superhero. In H.H. Jacobsen (ed.) The poetics of crime: understanding crime and deviance through creative sources. Routledge, London.

Young, A. (2014) From object to encounter: aesthetic politics and visual criminology. Theoretical Criminology 18.2, 159-175. 
Figure 1: Twilight Babes, Cookson Street

Figure 2: Exterior and interior door of a brothel in Cookson Street

Figure 3: Brothel entrance via alleyway behind Central Drive 